\title{
O DWÓCH KRAKOWSKICH PRAWNIKACH WYPROMOWANYCH W BOLONII NA POCZĄTKU XVI WIEKU
}

\author{
Stanisław A. Sroka
}

http://orcid.org/0000-0003-4059-7799

Uniwersytet Jagielloński w Krakowie

\section{ABSTRACT \\ ON TWO CRACOVIAN LAWYERS WHO WERE AWARDED UNIVERSITY DEGREES IN BOLOGNA IN THE EARLY $16^{\text {TH }}$ CENTURY}

At the beginning of the $16^{\text {th }}$ century, among the large group of Polish students in Bologna, there were also two Cracovian townsmen - Jan Albin and Mikołaj Waltek - who obtained a doctorate in canon law there. After returning from Bologna, Jan Albin (doctorate in 1504) first lectured at the Faculty of Law at the University of Cracow, but since he neglected his duties, he was removed from his post. Soon, he became the chancellor of the Vilnius bishop and came into possession of the Vilnius canonry. As a Vilnius canon, he became known as one of the editors of the statutes of the chapter, and he also performed the first visitation of the Vilnius diocese. In addition to the Vilnius canonry, he held other minor beneficiaries. He died in mysterious circumstances in Rome in 1528, from the wounds inflicted on him by German soldiers. Mikołaj Waltek, who obtained his doctorate in Bologna in 1509, after returning to Cracow became the archpriest of St. Mary's Church in 1512. He held the office of the archpriest until his death (c. 1554). As governor of St. Mary's Church, he was involved in a dispute with the Cracow councilors over the language of sermons preached in that church. In his will, he bequeathed his book collection ( 28 books) to the University of Cracow these books have been preserved until today (in the collection of the Jagiellonian Library).

Keywords: University of Bologna, Cracow in the 16th century, St. Mary's Church in Cracow, chapter of Vilna.

Słowa kluczowe: Uniwersytet Boloński, Kraków w XVI wieku, kościół Mariacki w Krakowie, kapituła w Wilnie.

Na początku XVI wieku w Bolonii studiowało wielu żaków z Polski. Przede wszystkim chcieli oni uzyskać doktorat z prawa kanonicznego, ale coraz liczniejsza grupa 
studiowała medycynę, otrzymując stopień doktorski z tej dziedziny ${ }^{1}$. Prawniczy doktorat z Bolonii dawał możliwość zrobienia kariery, jak pokazują to przykłady Polaków z drugiej połowy XV stulecia².

W niniejszym artykule skupiam uwagę na dwóch mieszczanach krakowskich, którzy na początku XVI wieku udali się na studia do Bolonii i otrzymali tam stopień doktora prawa kanonicznego. Byli to Jan Albin i Mikołaj Waltek. Ich bolońskie studia, jak również późniejsze kariery są prawie nieznane w dotychczasowej literaturze naukowej.

W oficjalnych aktach Uniwersytetu Bolońskiego notujących egzaminy doktorskie (tzw. libri secreti) pod dniem 5 września 1504 roku znajduje się zapis o egzaminie mieszczanina krakowskiego zwanego Johannes $\mathrm{Albi}^{3}$. Ta sama forma jego imienia, tym razem z podaniem imienia ojca (również Jana), została także zapisana w aktach prowadzonych przez uniwersyteckich notariuszy (tzw. acta notarum), mających charakter roboczy i służących do sporządzenia dyplomu doktorskiego ${ }^{4}$. Nie ulega wątpliwości, że ów mieszczanin krakowski, który sięgnął po doktorat z prawa kanonicznego w murach bolońskiej wszechnicy, to znany później Jan Albin, profesor prawa Uniwersytetu Krakowskiego i posiadacz kilku beneficjów, przede wszystkim kanonii wileńskiej. Jego studia bolońskie nie są znane w literaturze naukowej ${ }^{5}$. Późniejszy profesor prawa wywodził się z krakowskiej rodziny mieszczańskiej noszącej nazwisko Biały (Albus). Jego ojcem był krawiec Jan, a krewnymi kupiec Maciej

1 Być może przyszli lekarze zostali zwabieni karierą Macieja Sieprawskiego, który od 1509 r. wykładał w Bolonii chirurgię. Zob. Archivio di Stato di Bologna (dalej: ASB), Comune Governo, t. 390 (Libri partitorum, t. XIV), k. 148: „Item attentis meritis et doctrina magistri Matthie Seprauitii Poloni artium et medicine doctoris conducti ad legendum in hoc studio, in quo legit superior quinquennio et propter quem confluent quamplures scholares de partibus nationis sue"; F. Aulizio, Il polacco Mattias Sepravicius lettore all'Università di Bologna [w:] Atti del XVIII Congresso Italiano di storia della medicina, Sanremo 1962, s. 636-637; S.A. Sroka, Studenci z Polski dopuszczeni do prowadzenia zajęć na Uniwersytecie Bolońskim na poczatku XVI wieku, „Roczniki Historyczne” R. 84, 2018, s. 293-309; idem, Polish Surgeons in Bologna in the First Quarter of the Sixteenth Century, „Annali di storia delle università italiane" 2018, t. 22, nr 2, s. 115-122.

2 O polskich studentach w Bolonii w XV w. zob. J. Fijałek, Polonia apud Italos scholastica saeculum XV fasc. 1, Cracoviae 1900; S.A. Sroka, Wykaz Polaków wypromowanych na uniwersytecie w Bolonii $w$ drugiej polowie $X V$ w., „Kwartalnik Historyczny” 2014, t. 121, nr 1, s. 133-155; A. Hore czy, Prawnicze doktoraty Polaków w Bolonii w XV wieku, „Roczniki Historyczne” R. 81, 2015, s. 147-185.

3 ASB, Studio, nr 126 (Liber secretus iuris canonici), k. 180-180v. Zob. też: M.T. Guerrini, ,, Qui voluerit in iure promoveri..." I dottori in diritto nello Studio di Bologna (1501-1796), Bologna 2005, s. 123.

${ }^{4}$ ASB, Studio, nr 28 (Registri d'atti del collegio civile), k. 35: „Comparuit d. Johannes filius quondam alterius Johannis Albi civis Cracoviensis in Polonia scolaris studens Bononiensis in iure canonico".

5 V.Ališauskas, T. Jaszc zołt, L. Jova iša, M. Paknys, Lietuvos katalikų dvasininkai XIV-XVIa. (dalej: LKD), Vilnius 2009, s. 134-135; K. Ożóg, K. Fokt, M. Mikuła, M. Zdanek, D. Wójcik-Zega, K. Kuras, Profesorowie Wydziału Prawa Uniwersytetu Jagiellońskiego, t. 1: 1364-1780, red. W. Uruszczak, Kraków 2015, s. 108. 
i Bartłomiej Stachna ${ }^{6}$. Ten ostatni został na początku 1517 roku zabity przez kuśnierza krakowskiego, niejakiego Zebolta ${ }^{7}$.

Droga akademicka Albina rozpoczęła się w Krakowie. W 1497 roku uzyskał on stopień bakałarza sztuk wyzwolonych ${ }^{8}$ W bliżej nieznanym czasie znalazł się w Bolonii, gdzie studiował prawo kanoniczne. Tam uzyskał doktorat z tej dziedziny 5 września 1504 roku$^{9}$. Wkrótce potem wrócił do Krakowa i został inkorporowany na Wydział Prawa. Potwierdzają to między innymi rachunki prokuratora generalnego Uniwersytetu Krakowskiego z 1504 roku o wniesionej przez Albina opłacie w wysokości 3 florenów za nostryfikację doktoratu ${ }^{10}$. Od stycznia 1509 roku był on także seniorem Bursy Prawników ${ }^{11}$. Z tą posadą wiązało się posiadanie altarii pod wezwaniem Świętego Jana ante portam Latinam w katedrze krakowskiej ${ }^{12}$. W tym czasie jest również poświadczony jako surogat wikariusza generalnego Bernardyna Galla ${ }^{13}$. Z powodu zaniedbywania obowiązków usunięto go jednak z Uniwersytetu w 1510 roku $^{14}$. Dosyć szybko został kanclerzem biskupa wileńskiego Wojciecha Radziwiłła. Na tym urzędzie jest poświadczony po raz pierwszy 3 czerwca $1510 \mathrm{roku}^{15}$. W roku następnym wszedł w posiadanie kanonii wileńskiej. To benefi-

6 W. Urban, S. Lūžys, Cracovia Lithuanorum saeculis XIV-XVI, Vilnius 1999, s. 118, nr 106; LKD, s. 134.

7 Ibidem, s. 118, nr 107.

8 Najstarsza ksiega promocji Wydziatu Sztuk Uniwersytetu Krakowskiego z lat 1402-1541 (dalej: NKP), wyd. A. Gąsiorowski, T. Jurek, I. Skierska, Warszawa 2011, s. 261 [97/1B]. Późniejszy skryba uniwersytecki dopisał na marginesie taką notę: „,dictus Albinus, iuris pontificii doctor, canonicus Vilnensis, in Urbe per lancearios Germanos vulneratus, in Patauio moritur". Do treści tej noty odniosę się jeszcze w dalszej części artykułu.

9 Zob. wyżej.

10 Biblioteka Jagiellońska w Krakowie (dalej: BJ), rkps 248 (Rationarium antiquum procuratoris Universitatis Cracoviensi ab a. 1507-1518), k. 3: „Item a doctore Albino de Cracovia racione fisci et sue reversionis pro gradu doctoratus in decretis III fl, hoc est 1 marca III fert. et 6 gr.”; BJ, Inc. 2272 (J. Stoefflerinus, J. Pflaum, Almanach nova 1499-1531, Ulmae 1499 [diariusz Stanisława Aurifabera, nota pod dniem 16 XII 1504]. Zob. też: H. Barycz, Historia Uniwersytetu Jagiellońskiego w epoce humanizmu, Kraków 1935, s. 199; K. Ożóg, K. Fokt, M. Mikuła, M. Zdanek, D. Wójcik-Zega, K. Kuras, op. cit., s. 108. O urzędzie prokuratora generalnego Uniwersytetu Krakowskiego zob. W. Bukowski, $Z$ najstarszych dziejów skarbowości Uniwersytetu Krakowskiego. Rachunki prokuratorów generalnych za lata 1458-1490 [w:] Miasta, ludzie, instytucje, znaki. Księga jubileuszowa ofiarowana Profesor Bożenie Wyrozumskiej w 75. rocznicę urodzin, red. Z. Piech, Kraków 2008, s. 656-659.

11 BJ, Inc. 2272 (nota pod 25 I 1509).

12 J. Michalewicz, M. Michalewiczowa, Liber beneficiorum et benefactorum Universitatis Iagellonicae in saeculis XV-XVIII, t. I, p. 1, Cracoviae 1978, s. 37, nr 60; W. U rb an, S. Lūžy s, op. cit., s. 116, nr 101.

13 E. Knapek, Akta oficjalatu i wikariatu generalnego krakowskiego do połowy XVI wieku, Kraków 2010, s. 223.

14 BJ, rkps 248, k. 66v: „Item pro decreto privacionis doctoris Albini et pro copia eiusdem decreti notariis domini officialis VI gr. dedi”. Seniorat Bursy Prawników otrzymał wówczas Marcin Bełza z Krakowa. Zob. Conclusiones Universitatis Cracoviensis ab anno 1441 ad annum 1589, wyd. H. Barycz, Kraków 1933, nr 202.

15 LKD, s. 134; Regesty dokumentów diecezji wileńskiej z lat 1507-1522 Jana Fijałka i Władysława Semkowicza, wyd. G. Błaszczyk, „Lituano-Slavica Posnaniensia. Studia Historica” 2003, t. 9, nr 24; 
cjum dzierżył bardzo długo, bo aż do roku $1526^{16}$. Jan Albin często brał udział w posiedzeniach kapituły, o czym świadczą zachowane akta tejże instytucji ${ }^{17}$. W 1513 roku podarował katedrze wileńskiej srebrny kielich ${ }^{18}$. Z protokołów posiedzeń kapituły wileńskiej wynika, że bardzo angażował się w życie kapituły. W 1515 r. był jednym z redaktorów statutów nadanych jej przez biskupa Wojciecha Radziwiłła ${ }^{19}$. Ostateczny kształt tych statutów wykuwał się podczas licznych posiedzeń kapituły wileńskiej, zawsze z udziałem kanonika Jana Albina ${ }^{20}$. Czasami na posiedzeniach dochodziło do ostrych sporów, które skutkowały używaniem niegodnych słów pod adresem współbraci. W taki sposób w 1518 roku został obrażony Albin przez kanonika Wojciecha Wieleżyńskiego, za co ten został ukarany karą finansową w wysokości pół kopy groszy, którą musiał zapłacić w ciągu trzech dni ${ }^{21}$. Sam Albin również był czasami dokuczliwy. W 1522 roku skarżył się na niego prałat Wieżgajło, ponieważ Albin zrobił okno w ścianie przylegającej do domu prałata. Na posiedzeniu kapituły kazano Albinowi to okno zakryć22.

W marcu 1521 roku Albin znalazł się w więzieniu z polecenia legata papieskiego Zachariasza Ferreriego. Nieznane są okoliczności tej decyzji, wiadomo natomiast, że w sprawie uwolnienia wileńskiego kanonika interweniował sekretarz królewski Andrzej Krzycki, zarówno śląc listy do podkanclerzego Piotra Tomickiego, jak i osobiście rozmawiając $\mathrm{z}$ legatem i królem ${ }^{23}$. Wolność Albin odzyskał dopiero na wiosnę następnego roku. Na posiedzeniu kapituły wileńskiej 2 maja 1522 roku zdenerwowany żądał wydania pisma urzędowego zaświadczającego, że kapituła nie była

Acta primae visitacionis diocesis Vilnensis anno Domini 1522 peractae, ed. S.C. Row e11, Vilnius 2015, s. $125-126$.

16 J. Ochmański, Biskupstwo wileńskie w średniowieczu. Ustrój i uposażenie, Poznań 1972, s. 40; LKD, s. 134.

17 Obszerne wypisy z tych akt sporządził w pierwszej połowie XIX w. Mamert z Fulsztyna Herburt. Zob. Biblioteka Czartoryskich w Krakowie, rkps 3516 (Mamert z Fulsztyna Herburt, Aktów czyli dziejów kapituły katedralnej wileńskiej z siedmiu pierwszych tomów od 1501go do 1600go roku, Wilno 1843) (dalej: Herburt). Wypisy z niektórych posiedzeń kapituły opublikował J. Kurczewski, Kościót zamkowy czyli katedra wileńska w jej dziejowym, liturgicznym, architektonicznym i ekonomicznym rozwoju, t. III, Wilno 1916. Zob. też: W. Pawlikowska-Butterwick, L. Jovaiša, The Statutes of the Chapters of Vilna and Samogitia, Vilnius 2015, s. 148-151 (tutaj wynotowana obecność podczas posiedzeń kanoników kapituły, w tym Jana Albina, na których omawiano zagadnienia dotyczące przygotowywanych statutów kapituły wileńskiej); W. Pawlikowska, Wileńska kapituła katedralna w zapisie źródłowym. Część pierwsza: Ksawery Franciszek Michat Bohusz, Mamert Herburt z Fulsztyna, Jan Kurczewski - regestratorzy protokołów z posiedzeń kapituly, „Lituano-Slavica Posnaniensia. Studia Historica" 2007, t. 12, s. 118-124.

18 Skarbiec katedry wileńskiej, red. D. Nowacki, A. Saratowicz-Dudyńska, Warszawa 2008, s. 87, 95; LKD, s. 134.

19 W. Pawlikowska-Butterwick, L. Jovaiša, op. cit., s. 156, 164.

20 Ibidem, s. 148-151.

21 Herburt, s. 15 (par. 29); J. Kurczewski, op. cit., s. 9.

22 Herburt, s. 30 (par. 141); J. Kurczew ski, op. cit., s. 13. Warto dodać, że Jan Albin jako kanonik wileński zamieszkiwał w kamienicy kapitulnej przy ul. Zamkowej.

23. Acta Tomiciana, t. V, Poznań 1855, nr 386-388, 390. Sporu legata papieskiego z Janem Albinem nie oświetlają wydane akta działalności tego nuncjusza w Polsce. Zob. Acta nuntiaturae Polonae, t. II: Zacharias Ferreri (1519-1521) et nuntii minores (1522-1553), ed. H.D. Wojty ska, Romae 1992. 
zamieszana w jego uwięzienie, ani też nie wydała na ten czyn zgody ${ }^{24}$. W jesieni tego roku brał udział w rewizji skarbca katedry oraz przeprowadził w zastępstwie archidiakona pierwszą wizytację diecezji ${ }^{25}$.

W 1525 roku jeszcze jako kanonik wileński został kanclerzem nowego biskupa poznańskiego Jana Latalskiego ${ }^{26}$. W tym samym roku przestał być kanonikiem wileńskim. Oprócz kanonii wileńskiej, którą dzierżył wiele lat, Jan Albin jest poświadczony źródłowo jako posiadacz innych beneficjów. W listopadzie 1524 roku występuje jako proboszcz parafii Wiszniewo, zaś w dokumentach związanych z wykonaniem jego ostatniej woli jest wspomniany jako altarysta ołtarza Bożego Ciała w kościele Świętej Anny w Krakowie ${ }^{27}$. Jan Albin umarł zapewne w 1527 roku. Dosyć tajemnicze okoliczności jego śmierci zanotował skryba krakowskiego Uniwersytetu na marginesie noty o promocji bakalarskiej Albina, podając, że zakończył on życie w Padwie, ale w wyniku ran odniesionych w Rzymie od niemieckich żołnierzy ${ }^{28}$. Po zajęciu miasta przez wojska niemiecko-hiszpańskie Karola V (sacco di Roma) w maju 1527 roku wielu żołnierzy armii cesarskiej pozostało w nim aż do początku następnego roku. Zapewne ci żołnierze zranili przebywającego tam polskiego prawnika. Nie jesteśmy w stanie dokładnie określić przybliżonej daty jego śmierci, niemniej testamentem Albina (jako już zmarłego) zajmowano się w Krakowie 29 lutego 1528 roku, a wieści o jego śmierci musiały jeszcze dotrzeć z Italii nad Wisłę ${ }^{29}$. Przyjmuję zatem, że Albin umarł w 1527 roku. Podczas pobytu w Wiecznym Mieście mieszkał u Polki o imieniu Jadwiga, która opiekowała się nim także po jego zranieniu ${ }^{30}$. Zmarł zapewne w Rzymie, jak zapisano w aktach wikariusza generalnego krakowskiego ${ }^{31}$, chociaż skryba uniwersytecki podał, że doszło do tego w Padwie ${ }^{32}$. Wydaje się jednak mało prawdopodobne, aby po odniesieniu ran opuścił stolicę papiestwa i starał się w takim stanie wracać do ojczyzny.

Przed śmiercią spisał w Rzymie testament ${ }^{33}$. Z kilku rozproszonych przekazów źródłowych wiadomo, że w przekazał na rzecz kolegium prawniczego Uniwersytetu

24 Herburt, s. 24 (par. 72).

25 Ibidem, s. 28-29 (par. 121, 127); Acta primae visitacionis..., s. LXV-LXXVII.

26 Archiwum Kurii Metropolitalnej w Krakowie (dalej: AKM), Acta Officialia, t. 44, s. 1173; W. Urban, S. Lūžys, op. cit., s. 138, nr 162.

27 Wilno, Biblioteka Wróblewskich Akademii Nauk Litwy (Lietuvos Mokslų akademijos Vrublevskiu biblioteka), Oddział Rękopisów, VKF, nr 126: „presentibus: Joanne Albino decretorum doctore canonico Vilnensi, plebano in Wisniowo" (w dokumencie Pawła Holszańskiego, biskupa łuckiego; panu drowi Dominikowi Kadzikowi dziękuję za wykonanie fotografii tego dokumentu); LKD, s. 134-135; Wypisy źródtowe do dziejów Wawelu z archiwaliów kapitulnych i kurialnych krakowskich 1530-1533, wybór i oprac. B. Przybyszewski, Kraków 1986, nr 637, 671; M. Saj dak, Krag duchowieństwa kościoła św. Anny w średniowieczu, „Zeszyty Naukowe Towarzystwa Doktorantów UJ, Nauki Społeczne” 2014, nr 9(2), s. 81.

28 NKP, s. 261 [97/1B]: „dictus Albinus, iuris pontificii doctor, canonicus Vilnensis, in Urbe per lancearios Germanos vulneratus, in Patauio moritur".

29 AKM, Acta Officialia, t. 59, s. 691.

30 Ibidem, s. 1512: ,ipse olim doctor prefatus Albinus ab honesta Hedwigi Polona Rome tunc illius hospita".

31 Ibidem: ,,in Urbe vita functi”.

32 Zob. wyżej, przyp. 30.

33 AKM, Acta Officialia, t. 59, s. 1160: „testamento per testatorem Rome facto”. 
Krakowskiego 37 książek, zaś altaryście ołtarza Bożego Ciała w krakowskim kościele Świętej Anny Maciejowi Łąckiemu dał w użytkowanie okrągły srebrny pacyfikał z relikwiami świętych oraz z podobizną Świętej Anny Samotrzeć, który niegdyś ufundował na rzecz tegoż ołtarza ${ }^{34}$. Spadkobiercą Jana Albina była Katarzyna zwana Kaśką, jego siostrzenica (neptis). 20 października 1528 roku pokwitowała ona burgrabiemu zamku wileńskiego Ulrykowi Hossemu odbiór wszelkich należności pozostałych po jej krewnym ${ }^{35}$.

Drugim interesującym mnie w niniejszym tekście krakowskim prawnikiem, który uzyskał doktorat w bolońskiej wszechnicy na początku XVI stulecia, jest Mikołaj Waltek. Po powrocie z Italii przez wiele lat pełnił on urząd archiprezbitera kościoła Mariackiego w Krakowie. To do niego odnoszą się zapisy w księgach bolońskich z lat 1508 i 1509, informujące o uzyskaniu stopnia doktora z prawa kanonicznego przez niejakiego Mikołaja z Polski ${ }^{36}$. Problem w tym, że ów Mikołaj wpierw uzyskuje doktorat 5 września 1508 roku, a następnie 26 kwietnia 1509 roku $^{37}$. Trudno powiedzieć, czy chodzi o jedną i tę samą osobę, czy też o dwie. Maria T. Guerrini w wykazie doktorów prawa Uniwersytetu Bolońskiego z lat 1501-1796 zaznaczyłą ich oddzielnie, czyli potraktowała jak dwie różne osoby ${ }^{38}$. Trudno jednak zidentyfikować tegoż drugiego Mikołaja z Polski, który jako doktor prawa kanonicznego powinien się zaliczać do elity intelektualnej ówczesnego społeczeństwa w pierwszej połowie XVI wieku. Dominik Musialik w niepublikowanej pracy magisterskiej o rządcach parafii mariackiej w Krakowie, analizując wątek wykształcenia Mikołaja Waltka, przypuszcza, że w 1508 roku uzyskał on licencjat prawa kanonicznego, a rok później doktorat $^{39} . \mathrm{Z}$ akt bolońskich wynika, że Mikołaj był mężem uczonym i studiował w jednym $\mathrm{z}$ bolońskich kolegiów, któremu patronował wybitny prawnik Piotr d'Ancarano ${ }^{40}$.

Nasz tajemniczy Mikołaj to na pewno Waltek potwierdzony źródłowo na studiach w Bolonii w 1504 roku. Był wówczas świadkiem egzaminu doktorskiego z teologii

34 Ibidem; Wypisy źródłowe do dziejów Wawelu z archiwaliów kapitulnych i kurialnych krakowskich 1530-1533, nr 637, 671. Książki w większości spłonęły podczas wielkiego pożaru kolegium prawniczego w 1719 r. Zob. W. Szymborski, Collegium Broscianum, Kraków 2014, s. 54-57; S.A. Sroka et al., Collegium Iuridicum, Kraków 2015, s. 51. Kilka egzemplarzy, w tym dzieła Erazma z Rotterdamu, zachowało się do dzisiaj w zbiorach Biblioteki Jagiellońskiej. Zob. BJ, Oddział Rękopisów, Cimelia 97, 98; Katalog poloników XVI wieku Biblioteki Jagiellońskiej, t. 1, red. M. Malicki, E. Zwinogrodzka, Warszawa-Kraków 1992, s. 221-222, nr 729-730.

35 Herburt, s. 66 (par. 453); J. Kurczewski, op. cit., s. 30.

36 ASB, Studio, nr 126, k. 186, 188; nr 22, k. 13. Zob. też: S. Windakiewicz, Informacja o aktach Uniwersytetu Bolońskiego, „Archiwum do Dziejów Literatury i Oświaty w Polsce” 1892, t. 7, s. 135; M.T. Guerrini, op. cit., s. 128, 129.

${ }_{37}$ Zob. przypis poprzedni.

38 M.T. Guerrini, op. cit., s. 128, 129.

39 D. Musialik, Rządcy parafii pw. Wniebowzięcia Najświętszej Marii Panny w Krakowie w późnym średniowieczu i u progu czasów nowożytnych, Kraków 2010, s. 114 (praca magisterska w Zakładzie Historii Polski Średniowiecznej Instytutu Historii UJ).

40 ASB, Studio, nr 126, k. 186: „quia vir doctus et colegii bone memorie condam domini Petri de Ancharano scolaris". O tym kolegium pisał C. P i a na, Nuove ricerche su le Università di Bologna e di Parma, Quaracchi, Florentiae 1966, s. 418-433. 
Pawła z Zakliczewa ${ }^{41}$. Na tym egzaminie zebrała się całkiem spora grupka studentów z Polski. Oprócz Mikołaja Waltka znaleźli się tam: Stanisław Oleśnicki, wówczas kanonik gnieźnieński, Bernard Wapowski, wówczas kanonik krakowski, Piotr Opaliński dzierżący wtenczas kustodię poznańską, kanonik poznański Jan Górski oraz niejaki Jan Fristacius, kleryk diecezji krakowskiej ${ }^{42}$. Nie ulega zatem wątpliwości, że Mikołaj Waltek, student boloński w 1504 roku, kilka lat później uzyskał doktorat z prawa kanonicznego, zwłaszcza że po powrocie do Krakowa posługiwał się, już jako proboszcz kościoła Mariackiego, tym stopniem naukowym.

Mikołaj Waltek, zanim przybył do Bolonii, studiował w Krakowie, gdzie zapisał się na Wydział Sztuk Wyzwolonych w 1493 roku $^{43}$. Stopień bakałarza uzyskał w 1497 roku, a magistra - w 150144. W literaturze naukowej jest prawie nieobecny. Biogram Waltka zamieścił Bolesław Przybyszewski w przypisie do swojego wydawnictwa źródłowego dotyczącego Wawelu ${ }^{45}$, a przede wszystkim Dominik Musialik we wspomnianej już pracy magisterskiej o rządcach parafii mariackiej ${ }^{46}$.

Dosyć skomplikowane są koligacje rodzinne Waltka. Na odwrocie dokumentu z 1519 roku, gdy był już proboszczem kościoła Mariackiego w Krakowie, ówczesną ręką zapisano streszczenie wydanego aktu, określając Mikołaja Waltka jako „Nicolaus Kyzyngier alias Waltek" ${ }^{\prime 7}$. Nasz uczony jurysta pochodził zatem z krakowskiej rodziny mieszczańskiej Kesingerów, znanej bardziej jako Kislingowie. Mikołaj natomiast używał nazwiska swojego ojca Jana Kislinga zwanego Waltkiem ${ }^{48}$. Do metryki Uniwersytetu Krakowskiego Waltek wpisał się jako Nicolaus Johannis de Craco$v i a^{49}$, zatem jego ojcem był Jan, który w literaturze jest utożsamiany z Janem Kislingiem, znanym rajcą odgrywającym w Krakowie ważną rolę w pierwszej ćwierci XVI wieku ${ }^{50}$. Matką Mikołaja była Barbara, córka Mikołaja Krejdlara, burgrabiego

41 C. Piana, Ricerche su le Università di Bologna e di Parma nel secolo XV, Quaracchi, Florentiae 1963, nr 137, s. 236-237: „Nicolao Waltek de Cracovia”. Zob. też Laudatio Bononiae. Atti del Convegno storico italo-polacco svoltosi a Bologna dal 26 al 31 maggio 1988 in occasione del Nono Centenario dell'Alma Mater Studiorum, a cura di R.C. Lew an ski, Varsaviae 1990, s. 495.

42 C. Piana, Ricerche..., nr 137, s. 237.

${ }_{43}$ Metryka Uniwersytetu Krakowskiego z lat 1400-1508, t. 1, wyd. A. Gąsiorowski, T. Jurek, I. Skierska, przy współpracy R. Grzesika, Kraków 2004, s. 509 [93e/060].

${ }^{44}$ NKP, s. 261 [97/12B], 264 [1501/10M].

45 Wypisy źródłowe do dziejów Wawelu z archiwaliów kapitulnych i kurialnych krakowskich 15391541, wybór i oprac. B. Przyby szew ski, Kraków 1991, nr 631, s. 107-108.

46 D. Musialik, op. cit., s. 113-117.

47 E. Dłu go polski, Katalog kościoła N.P. Maryi w Krakowie, „Teka Grona Konserwatorów Galicyi Zachodniej” 1916, t. 6, s. 88, nr 162.

48 J. Rajman, Kesingerowie krakowscy w XIV-XV wieku [w:] Ojczyzna bliższa i dalsza. Studia historyczne ofiarowane Feliksowi Kirykowi w sześćdziesiata rocznicę urodzin, red. J. Chrobaczyński, A. Jureczko, M. Śliwa, Kraków 1993, s. 442.

49 Metryka Uniwersytetu Krakowskiego..., s. 509 [93e/060].

50 S. Pańków, Kisling Jan (zm. 1534), mieszczanin i rajca krakowski [w:] Polski Stownik Biograficzny (dalej: PSB), t. 12, Wrocław 1966-1967, s. 502-503; Z. Nog a, Urzędnicy miejscy Krakowa, cz. 2: 1500-1794, Kraków 2008, s. 3 i n.; M. Starzyński, Krakowska rada miejska w średniowieczu, Kraków 2010, s. 299. 
krakowskiego i żupnika olkuskiego, którą po śmierci męża poślubił znany krakowski rajca Kasper Ber ${ }^{51}$.

Po powrocie do Krakowa ze studiów włoskich w niedługim czasie Waltek objął godność archiprezbitera kościoła Mariackiego. Król Zygmunt Stary dokonał prezenty Mikołaja na ten wakujący wówczas urząd biskupowi krakowskiemu 15 marca 1512 roku $^{52}$. Godność tę Waltek piastował aż do śmierci, która nastąpiła około $1554 \mathrm{roku}^{53}$. Z okresu sprawowania urzędu warto tutaj wspomnieć o konflikcie archiprezbitera z rajcami krakowskimi o język kazań w mariackiej świątyni. 14 października 1527 roku biskup krakowski Piotr Tomicki wydał w tym sporze wyrok, nakazując archiprezbiterowi utrzymywać przy kościele Mariackim sześciu wikarych znających zarówno język polski, jak i niemiecki oraz żywić kaznodzieję niemieckiego i jego służącego ${ }^{54}$. Dopiero w 1537 roku Zygmunt Stary nakazał przenieść kazania w języku niemieckim do kościoła Świętej Barbary. Kazania po polsku miały być głoszone w kościele Mariackim. Ostatecznie ustalił się taki porządek kazań, że w niedziele i święta w kościele Mariackim przed południem były kazania po polsku, natomiast kaznodzieja niemiecki głosił kazania po południu przed nieszporami. W kościele Świętej Barbary było odwrotnie, czyli przed południem kazania po niemiecku, zaś po polsku przed wieczornymi nieszporami ${ }^{55}$.

Waltek wielokrotnie wchodził w różnego rodzaju spory. W 1541 roku odmówił katolickiego pochówku karczmarzowi Janowi Jezuskowi, a to z tego powodu, że ten podobno przed śmiercią nie przyjął świętych sakramentów. Zgodę na katolicki pogrzeb wyraził dopiero wikariusz generalny krakowski Benedykt Izdbieński. Przed jego oblicze wdowa po Jezusku, Barbara, przyprowadziła dwóch świadków, którzy potwierdzili przyjęcie sakramentów przez zmarłego ${ }^{56}$.

Jako archiprezbiter mariacki Mikołaj Waltek zgromadził wiele beneficjów (podaje je w swojej pracy D. Musialik). Był altarystą w wielu miejscach (m.in. w krakowskich kościołach: Mariackim, św. Barbary, św. Anny, ale także w Wieliczce i Radomiu). Jest również potwierdzony jako pleban w Pałecznicy ${ }^{57}$. W 1529 roku wchodził w skład sądu inkwizycyjnego, który skazał na więzienie za apostazję Katarzynę Weiglową, wdowę po rajcy krakowskim Melchiorze. Po dziesięcioletnim pobycie w więzieniu została ona spalona żywcem na stosie na Małym Rynku

51 J. Ptaśnik, Obrazki z przeszłości Krakowa, Biblioteka Krakowska 23, Kraków 1903, s. 19-21; K. Pieradzka, Kreydler Mikołaj, PSB, t. 15, Wrocław 1970, s. 292-293; Burgrabiowie zamku krakowskiego XIII-XV wieku. Spisy, oprac. W. Bukowski, Kórnik 1999, nr 97; M. Starzyński, op. cit., s. 300; D. Musialik, op. cit., s. 115.

52 Matricularum Regni Poloniae Summaria, ed. T. Wierzbow ski, pars IV, vol. 1, Varsoviae 1910, nr 1487; D. Musialik, op. cit., s. 114, 116.

53 D. Musialik, op. cit., s. 114-115.

54 Z. Nog a, Krakowska rada miejska w XVI wieku. Studium o elicie władzy, Kraków 2003, s. 172.

55 J. Wolny, Kaznodziejstwo katedralne w Krakowie na tle środowiska (okres 1520-1584) [w:] Cracovia litterarum. Kultura umysłowa i literacka Krakowa i Małopolski w dobie Renesansu, red. T. Ulewicz, Kraków 1991, s. 289; Z. Nog a, Krakowska rada ..., s. 172-173.

56 Wypisy źródlowe do dziejów Wawelu z archiwaliów kapitulnych i kurialnych krakowskich 1539 $1541, \mathrm{nr} 792$.

57 D. Musialik, op. cit., s. 114. 
w Krakowie ${ }^{58}$. Waltek był także członkiem dwóch krakowskich bractw religijnych (św. Ducha i Wniebowzięcia NMP) ${ }^{59}$. Podobnie jak Jan Albin legował swój księgozbiór (28 książek) na rzecz krakowskiego Uniwersytetu. Książki te przetrwały do dnia dzisiejszego, albowiem zasiliły bibliotekę teologów w kolegium większym, którego nie spotkał los Collegium Iuridicum ${ }^{60}$. Nie znamy dokładnej daty śmierci Mikołaja Waltka, umarł jednak, jak wspomniałem, około roku $1554^{61}$.

\section{BIBLIOGRAFIA}

\section{Źródła archiwalne}

Archivio di Stato di Bologna

Comune Governo, t. 390 (Libri partitorum, t. XIV).

Studio, nr 22 (Registri d'atti del collegio canonico).

Studio, nr 28 (Registri d'atti del collegio civile).

Studio, nr 126 (Liber secretus iuris canonici).

Archiwum Kurii Metropolitalnej w Krakowie

Acta Officialia, t. 44, 59.

Biblioteka Czartoryskich w Krakowie

rkps 3516 (Mamert z Fulsztyna Herburt, Aktów czyli dziejów kapituły katedralnej wileńskiej z siedmiu pierwszych tomów od 1501go do 1600go roku, Wilno 1843).

Biblioteka Jagiellońska w Krakowie

rkps 248 (Rationarium antiquum procuratoris Universitatis Cracoviensi ab a. 1507-1518).

Inc. 2272 (J. Stoefflerinus, J. Pflaum, Almanach nova 1499-1531, Ulmae 1499).

Cimelia 97, 98.

Wilno, Biblioteka Wróblewskich Akademii Nauk Litwy (Lietuvos Mokslų akademijos Vrublevskių biblioteka)

Oddział Rękopisów, VKF, nr 126.

58 J. Tazbir, Sprawa Weiglowej w świetle źródet archiwalnych [w:] Historia i wspótczesność, red. E. Frącki, Warszawa 1987, s. 49-58; W. Urban, Dwa szkice z dziejów reformacji, Kielce 1991, s. 25-29; Z. Noga, Krakowska rada..., s. 182.

59 D. Musialik, op. cit., s. 114.

60 W. Wisłocki, Incunabula typographica Bibliothecae Universitatis Jagellonicae Cracoviensis, Cracoviae 1900, s. 534-535; D. Musialik, op. cit., s. 114.

61 Zob. przyp. 45. 


\section{Źródła drukowane}

Acta nuntiaturae Polonae, t. II: Zacharias Ferreri (1519-1521) et nuntii minores (15221553), ed. H.D. Wojtyska, Romae 1992.

Acta primae visitacionis diocesis Vilnensis anno Domini 1522 peractae, ed. S.C. Rowell, Vilnius 2015.

Acta Tomiciana, t. V, Poznań 1855.

Bukowski W., Z najstarszych dziejów skarbowości Uniwersytetu Krakowskiego. Rachunki prokuratorów generalnych za lata 1458-1490 [w:] Miasta, ludzie, instytucje, znaki. Księga jubileuszowa ofiarowana Profesor Bożenie Wyrozumskiej w 75. rocznicę urodzin, red. Z. Piech, Kraków 2008, s. 653-713.

Conclusiones Universitatis Cracoviensis ab anno 1441 ad annum 1589, wyd. H. Barycz, Kraków 1933.

Długopolski E., Katalog kościoła N.P. Maryi w Krakowie, „Teka Grona Konserwatorów Galicyi Zachodniej” 1916, t. 6.

Katalog poloników XVI wieku Biblioteki Jagiellońskiej, t. 1, red. M. Malicki, E. Zwinogrodzka, Warszawa-Kraków 1992.

Matricularum Regni Poloniae Summaria, ed. T. Wierzbowski, pars IV, vol. 1, Varsoviae 1910.

Metryka Uniwersytetu Krakowskiego z lat 1400-1508, t. 1, wyd. A. Gąsiorowski, T. Jurek, I. Skierska, przy współpracy R. Grzesika, Kraków 2004.

Najstarsza księga promocji Wydziału Sztuk Uniwersytetu Krakowskiego z lat 1402-1541, wyd. A. Gąsiorowski, T. Jurek, I. Skierska, Warszawa 2011.

Regesty dokumentów diecezji wileńskiej z lat 1507-1522 Jana Fijałka i Władysława Semkowicza, wyd. G. Błaszczyk, „Lituano-Slavica Posnaniensia. Studia Historica” 2003, vol. 9.

The Statutes of the Chapters of Vilna and Samogitia, ed. W. Pawlikowska-Butterwick, L. Jovaiša, Vilnius 2015.

Urban W., Lūžys S., Cracovia Lithuanorum saeculis XIV-XVI, Vilnius 1999.

Wypisy źródłowe do dziejów Wawelu $z$ archiwaliów kapitulnych i kurialnych krakowskich 1530-1533, wybór i oprac. B. Przybyszewski, Kraków 1986.

Wypisy źródłowe do dziejów Wawelu z archiwaliów kapitulnych i kurialnych krakowskich 1539-1541, wybór i oprac. B. Przybyszewski, Kraków 1991.

\section{Opracowania}

Ališauskas V., Jaszczołt T., Jovaiša L., Paknys M., Lietuvos katalikų dvasininkai XIVXVI a., Vilnius 2009.

Aulizio F., Il polacco Mattias Sepravicius lettore all'Università di Bologna [w:] Atti del XVIII Congresso Italiano di storia della medicina, Sanremo 1962, s. 630-642.

B arycz H., Historia Uniwersytetu Jagiellońskiego w epoce humanizmu, Kraków 1935.

Burgrabiowie zamku krakowskiego XIII-XV wieku. Spisy, oprac. W. Bukowski, Kórnik 1999.

Fijałek J., Polonia apud Italos scholastica saeculum XV, fasc. 1, Cracoviae 1900.

Guerrini T.M, ,Qui voluerit in iure promoveri...” I dottori in diritto nello Studio di Bologna (1501-1796), Bologna 2005.

Horeczy A., Prawnicze doktoraty Polaków w Bolonii w XV wieku, „Roczniki Historyczne” R. 81, 2015, s. 147-185. 
Knapek E., Akta oficjalatu i wikariatu generalnego krakowskiego do połowy XVI wieku, Kraków 2010.

Kurczewski J., Kościół zamkowy czyli katedra wileńska w jej dziejowym, liturgicznym, architektonicznym i ekonomicznym rozwoju, t. III, Wilno 1916.

Laudatio Bononiae. Atti del Convegno storico italo-polacco svoltosi a Bologna dal 26 al 31 maggio 1988 in occasione del Nono Centenario dell'Alma Mater Studiorum, a cura di R.C. Lew anski, Varsaviae 1990.

Michalewicz J., Michalewiczowa M., Liber beneficiorum et benefactorum Universitatis Iagellonicae in saeculis XV-XVIII, t. V, pars 2, Cracoviae 1991.

Musialik D., Rządcy parafii pw. Wniebowzięcia Najświętszej Marii Panny w Krakowie w późnym średniowieczu i u progu czasów nowożytnych, Kraków 2010 (praca magisterska w Zakładzie Historii Polski Średniowiecznej Instytutu Historii UJ).

Noga Z., Krakowska rada miejska w XVI wieku. Studium o elicie władzy, Kraków 2003.

Noga Z., Urzędnicy miejscy Krakowa, cz. 2: 1500-1794, Kraków 2008.

Ochmański J., Biskupstwo wileńskie w średniowieczu. Ustrój i uposażenie, Poznań 1972.

Ożóg K., Fokt K., Mikuła M., Zdanek M., Wójcik-Zega D., Kuras K., Profesorowie Wydziału Prawa Uniwersytetu Jagiellońskiego, t. 1: 1364-1780, red. W. Uruszczak, Kraków 2015.

Pańków S., Kisling Jan (zm. 1534), mieszczanin i rajca krakowski [w:] Polski Stownik Biograficzny, t. 12, Wrocław 1966-1967, s. 502-503.

Pawlikowska W., Wileńska kapituła katedralna $w$ zapisie źródłowym. Część pierwsza: Ksawery Franciszek Michat Bohusz, Mamert Herburt z Fulsztyna, Jan Kurczewski - regestratorzy protokołów z posiedzeń kapituly, „Lituano-Slavica Posnaniensia. Studia Historica" 2007, t. 12, s. 118-124.

Piana C., Nuove ricerche su le Università di Bologna e di Parma, Quaracchi, Florentiae 1966.

Piana C., Ricerche su le Università di Bologna e di Parma nel secolo XV, Quaracchi, Florentiae 1963.

Pieradzka K., Kreydler Mikołaj [w:] Polski Słownik Biograficzny, t. 15, Wrocław 1970, s. 292-293.

Ptaśnik J., Obrazki z przeszłości Krakowa, Biblioteka Krakowska 23, Kraków 1903.

Rajman J., Kesingerowie krakowscy w XIV-XV wieku [w:] Ojczyzna blizssza i dalsza. Studia historyczne ofiarowane Feliksowi Kirykowi w sześćdziesiąta rocznice urodzin, red. J. Chrobaczyński, A. Jureczko, M. Śliwa, Kraków 1993, s. 435-445.

Sajdak M., Krag duchowieństwa kościoła św. Anny w średniowieczu, „Zeszyty Naukowe Towarzystwa Doktorantów UJ, Nauki Społeczne" 2014, nr 9(2), s. 65-86.

Skarbiec katedry wileńskiej, red. D. Nowacki, A. Saratowicz-Dudyńska, Warszawa 2008.

Sroka S.A., Polish Surgeons in Bologna in the First Quarter of the Sixteenth Century, „Annali di storia delle università italiane" 2018, t. 22, nr 2, s. 115-122.

Sroka S.A., Studenci z Polski dopuszczeni do prowadzenia zajęć na Uniwersytecie Bolońskim na początku XVI wieku, „Roczniki Historyczne” R. 84, 2018, s. 293-309.

Sroka S.A., Wykaz Polaków wypromowanych na uniwersytecie w Bolonii w drugiej połowie $X V w .$, ,Kwartalnik Historyczny” 2014, t. 121, nr 1, s. 133-155.

Sroka S.A. et al., Collegium Iuridicum, Kraków 2015.

Starzyński M., Krakowska rada miejska w średniowieczu, Kraków 2010.

Szymborski W., Collegium Broscianum, Kraków 2014.

Tazbir J., Sprawa Weiglowej w świetle źródel archiwalnych [w:] Historia $i$ wspótczesność, red. E. Frącki, Warszawa 1987, s. 49-58.

Urban W., Dwa szkice z dziejów reformacji, Kielce 1991. 
Windakiewicz S., Informacja o aktach Uniwersytetu Bolońskiego, „Archiwum do Dziejów Literatury i Oświaty w Polsce" 1892, t. 7, s. 130-148.

Wisłocki W., Incunabula typographica Bibliothecae Universitatis Jagellonicae Cracoviensis, Cracoviae 1900.

Wolny J., Kaznodziejstwo katedralne w Krakowie na tle środowiska (okres 1520-1584) [w:] Cracovia litterarum. Kultura umystowa i literacka Krakowa i Małopolski $w$ dobie Renesansu, red. T. Ulewicz, Kraków 1991, s. 285-318. 